\title{
Pidginized English Formation by Art Shop Attendants in Seminyak Street
}

\author{
Ni Putu Kiki CintyaYunira*, I Nyoman Triediwan, I Komang Sumaryana Putra \\ English Department, Faculty of Arts, Udayana University \\ [kintyayunira@gmail.com],[tri_ediwan@unud.ac.id],[komangsumaryana@gmail.com] \\ Klungkung, Bali, Indonesia \\ *Corresponding author
}

\begin{abstract}
This study aimed at finding out forms of pidginized English which used by the shop attendants in Seminyak. The data was analyzed qualitatively. Population and Sample Techniques was based on the sociolinguistics theory, particularly the theories of Wardhaugh (1986), Holmes (1992), Hudson (1980), Todd (1984), and Quirk and Greenbaum (1985). The method of collecting data used in this data was observation, interview and questionnaire. The data was collected by note taking technique by observing the shop attendance when ever they speak English with foreign customers. The Findings showed that the forms of pidginized Englishused by the shop attendants was positive, negative, and interrogative forms. As for the functions they used expressive, descriptive, argumentative, and signaling function.
\end{abstract}

Keywords: Pidginized English, Standard English, Art Shop Attendants.

\section{INTRODUCTION}

According to Todd (1981;10 language is an arbitrary set of signs by which members of a speech community communicated and co-operate. Language is a set of sound system which follows certain rules within itself.

Language depicted as a window or bridge of the world. It is very important for people to learn foreign language. English is one of the language that spoken as International language. Bali has the most famous tourist attractions for local people or foreigners. English as International language used to communicate between local people and foreigners in Bali.

The art shop attendants mostly do not really understand how to speak and listen English clearly. They try to make conversation by creating their own terms and expression which are different from the Standard English. Trudgill (1995:5-6) defined Standard English as a variety of English which is usually used in print, and which is normally taught in schools and to non-native speakers learning the language.

According to Wardaugh (1966:57), a pidgin is sometimes regarded as a 'reduced' variety of a 'normal' language, with simplification of the grammar and vocabulary of that language, considerable phonological variation, and an admixture of local vocabulary to meet the special needs of the contact groups.

Initially when pidgin develop to serve a very narrow range of functions. Those who use them have other language too. So pidgin is an additional language to their linguistic repertoire used for a specific purpose.

According to Holmes (1992: 90), a pidgin is a language, which has no native speakers, and develops as a means of communications between people who do not have the common language. Holmes (1992) considering pidgin develop as a means of communication between people who do not have the common language. So a pidgin is no one's native language. Pidgin seems particularly likely to arise when two groups with the different languages are communicating in a situation where there is also a third dominant language.

According to Oxford Advance Learner's Dictionary (2010:1367), shop attendant is a person whose job is to serve customers in a shop/store. Those definition come from two definitions of: first, shop is a building or part of building where you can 
buy goods or services (Oxford Advance Learner's Dictionary (2010:1367), second attendant is a person whose job is to serve or help people in a public place (Oxford Advance Learner's Dictionary (2010:80).

Bellrose (2001) from international journal entitled Computer Pidgin Language: A new language to talk to your computer? The aims of the study were to teach people a new language that is efficient for dialogues with computers-a sort of artificial spoken language. The data of the paper was analyzed by exploring some of the wider implications of CPL and longer-term research directions. The difference of the paper to this study is the paper focused on pidgin language in computer while this study focuses on pidginized English in real life. The similarity of the paper with this study is they both concern about the relevance and importance of pidgin language. There were still a lot of theory that had not been proven in the paper. However, the idea was brilliant and will be very useful if the paper realized.

Donald Winford (2010) entitled "Journal of artificial language and Creole Languages". This article provides a fortune for the scholarly study of pidgins, creoles, and other contact language varieties, from multi-disciplinary perspectives. The journal places special emphasis on current analysis devoted to empirical description, theoretical issues, and the broader implications of the study of contact languages for theories of language acquisition and alter, and for linguistic theory in general. This journal also explores the application of linguistic analysis to language designing, education, and social reform, as well as studies that examine the role of contact languages within the social life and culture, including the literature, of their communities.

Dellis Pratika (2016) entitled "The Existence of Indonesian Language: Pidgin or Creole" aimed to determine whether the Indonesian language was categorized into pidgin or creole. The data of the paper used library study to find the data since it was not possible to trace the data in the field. The result of the study revealed that Indonesian was not either pidgin or creole since the characteristics features did not meet any of them. It is believed that the Indonesian language was one of the means to achieve independence, but it is opened to receive lexicons from other foreign languages as the words keep increasing each year that can be seen in Kamus Besar Bahasa Indonesia (KBBI).

Christine I. Ofulue (2012) entitled "Nigerian Pidgin and West African Pidgins: A sociolinguistic perspective." This study aims to fill the gap by providing acomparative analysis of similarities and differences in current domains of use, functions, and attitudes that have shaped their current status in the context of their socio-historical interrelatedness. The study shows that while the WAPE varieties share similarities in their demographic and sociolinguistic contexts, they differ in status. It observes a more rapid development and expansion in NP. The findings of this study contribute to a holistic understanding of the role of sociolinguistic factors in evaluating the status of the mutually intelligible WAPE varieties to inform its future development.

Asikiya Amakari (2015) entitled The Effect of Pidgin in the Teaching and Learning of Standard English in Nigeria". This study was aimed at investigating how the Pidgin variety of the English language, otherwise known as "Brokin", has influenced the teaching and learning of the Standard English variety in Nigeria. This paper surveyed the origin of the Nigerian Pidgin and its features, made semantic comparisons with the Pidgin and Standard English. It also x-rayed the extent to which Pidgin has influenced the teaching and learning of the Standard English.

Jacob O. Alobo (2015) entitled "Pidgin English as a Vehicle for the Promotion of Peaceful CoExistence and National Unity in Nigeria". This study views pidgin as a distinct language, rich, viable and capable of being used for any form of discourse, including the academic. This study discuss how Pidgin can be used as a vehicle for the promotion of peaceful co-existence and national unity, and makes some recommendations towards ameliorating situation. It concludes by encouraging government at all levels to strengthen Pidgin by way of developing it in order to effectively and actively performs the role of promoting peaceful co-existence and national unity in Nigeria.

Beatrice Ekajume-Ilongo (2016) entitled "An Overview of te Pidgin English in Cameroon". This study shows that Cameroon Pidgin English (CPE) is viable,flexible and practical, and that Cameroonians are more comfortable using this language, which they consider to be an indigenous language, than using either French or English the official language. The study argues that if they are enough written material and text books on CPE, it will be an appropriate language for use as a medium of instruction in the early years of schooling and for education of Cameroonian adult illiterates.

Ni Putu Yeni Andriyani (2013) entitled "An Analysis of Pidgin English Used by Tourism Police at Lake Beratan Tourism Object, Bali". This study aimed at finding out the forms, meanings, and function of Pidgin English Used by Tourism Police when communicating with English-speaking tourist. This study was conducted at Lake Beratan Tourism Object, Bali. This study designed by using descriptive qualitative method approach in which the data collected were analysed qualitatively.

Made Yuni Swari (2016) entitled "Pidginized English Formation by Traders at Kerthegosa Museum". This study conducted to find out the form of English pidgin used by traders in Kerthagosa and to find the factors that the used of pidgin by Traders in Kerthagosa. This research used theory by Holmes (1992) and Wardaugh (1986). 
Vergilius Bage Ola Unagolok (2014) entitled "Language Contact between Tourist and Traders in Kuta Beach". This study aims to know the phenomenon that occurred in language contact between traders and buyers at Kuta Beach, and to identify the factors contributing to the language. This study used observation, recording, note taking techniques and interview. This study used qualitative method for analysing.

Meynar Clavarius Audito Pamungkas (2014) entitled "Pidginized English Spoken by Handicraft Sellers in Sanur". This study aimed to identify and describe the form of the Pidgin Used by handicraft sellers in Sanur Beach. Second to analyse the factors contributing the Pidgin English. This study conducted Sanur Beach. This study designed by using descriptive qualitative method approach in which the data collected were analysed qualitatively.

Adi Jaya Windu (2015) entitled "Language Variants Used by Gamers in Ragnarok Online II: Legend of The Second South East Asia”. This study aimed to finding out the phenomenon of language change used by the gamers in online game and knowing the meaning also analyse why the gamers use the phenomenon of language change among them. This study directly collected from the gamers online chat conversation of the game. This study designed by using descriptive qualitative method.

Based on the background the research problems of this study are:

a. What forms of pidginized English that were spoken by art shop attendants in Seminyak Street?

b. What are the functions of pidginized English that were expressed by art shop attendants in Seminyak Street?

\section{MATERIAL AND METHOD}

Seminyak Street was chosen as the research location because English is commonly used to communicate between the art shop attendants and the foreign customers. There 10 art shop attendants in Seminyak Street were taken as samples. The method used in collecting the data is, interview, questionnaire, and observation.

The data analyzed qualitative. First, the collected data were gathered and classified into some appropriate classes by using a Sociolinguistic theory by Wardaugh (1986) in his book entitled $A n$ Introduction to Socioinguistic. Second all classified data was compare with Standards English Grammar based on the book entitled "A Comprehensive Grammar of the English Language" by Quirk and Greenbaum (1985).

\section{RESULT AND DISCUSSION}

From the discussion, writer found the results as follow:
3.1 Grammar Form of English Pidgin that are used by Art Shop Attendants in Seminyak Street

The collected data which is in the form of conversations were analyzed in terms of Pidginized English forms and the language functions used in the conversation between art shop attendant and foreigners in Seminyak Street, based on the theory about the criteria of Pidgin proposed by Muhlhausler and the analysis of language functions use proposed by Muhlhausler.

\subsubsection{Pidginized English in Positive Forms is}

classified into three divisions such as:

There are positive sentences used by art shop attendants in Seminyak Street, which can be commercially with Standard English from grammatical point of view. For example:

(1) Can bargain this one, Sir

(2) This good than other shops

(3) Tomorrow-tomorrow, see you again

Example (1) performs errors such as absence of subject, as well as absence of preposition. The problems occur as the result of the intention to simplify the word order and the speakers do not tend to embed them. The sentence in English should be formed by Subject + Verb/to be. In this case, the sentence does not have subject. The subject needed for example (1) that is "You" which refers to the person whom the art shop attendant was talking to. The preposition "for" in order to be followed by noun "this one" is also needed in example (1).

In example (2), again the absence of "to be" has occurred. Both examples must use "is" as to be after "this" as the determiners, which refers to singular noun. In example (2) there is also an error in using degrees of comparison of adjective "good". In order to compare two or more objects, degrees of comparison needs to be applied to the sentence. In example (2), two objects are being compared, the one belongs to the vendor, and another belongs to the other shop. The comparative degree for "good" is better.

In example (3), the expression "tomorrow-tomorrow" appears from local vocabulary, Bahasa Indonesia, which means "besok-besok". In Bahasa Indonesia, "besok-besok" means next time.

\section{a. Positive Instructions}

The ideas of the Standard English which are composed by experts are supported by the data found at Seminyak Street during the investigation of the art shop attendants. The speakers use the expression in simple ways, combined with the new terms, vocabularies used by their society only. For example:

1. Hello, see here please.

2. Come here, free looking. 
Another concept of pidginize English is to attempt or adding in order to simplify the sentence elements, such as the vocabulary, grammar, phonological variation and mix with the local vocabulary. Some words derived from local vocabulary are used here, such as "ya" which mean "Okay"

The data found is quite clear to show the validity of pidginizing English at Seminyak Street. The Standard English counterparts of those expressions used by art shop attendant at Seminyak Street should be:

1. Hello, please come here to look.

2. Come here, please. It is free to look.

\section{b. Positive Offerings}

When carrying out the observation, the same case was found in pidginize forms of English at Seminyak Street. The speakers speak in simple languages which has wrong grammatical. The new terms or words are not used in accordance with word orders in the sentence, so that it sounds odd but somehow it expresses the desired context from shop attendant. The examples of this form are:

1. Halo, rattan bag, Sir?

2. Halo, tattoo, tattoo?

If it is compared to the grammatical aspect of Standard English, the forms should be as follows:

1. Hello, would you like to buy some rattan bag?

2. Hello, would you like to make a tattoo?

\subsubsection{Pidginized English in Negative Forms}

Like the positive forms above, negative forms also occur in pidginize English at Seminyak Street. Quirk and Greenbaum (1973: 183) states that the negation of a sentence is accomplished by inserting not, n't between Subject and Predicate.

\section{a. Negative Statements}

Concerning to the negative forms of Seminyak Street pidginize English, Todd (1984:5), again gives his ideas that in pidginize English, negation involves the use of one negative marker, no in this pidgin. This can be understood in the following example:

- No money...no money...no money

- Don't have money

The sentence above is identified as negative statements, where it is formed by adding negative marker no.

\section{b. Negative Instructions}

If we are compared with the data of Seminyak Street Pidginized English, some quite similar data was found as representative examples of this language variety. Based on the data, the speakers do not seem to be aware of being mistaken in arranging the sentences. They just simplify the use of the world "DO NOT" in certain or any places.

The data collected at Seminyak Street, there are some examples of negative instruction:
1. You not bargain very low

2. No cash, no buy, sir

The forms, of negative instruction of pidginized English in Seminyak Street are only marked by the word "NOT" and do not use "DO".

Those data can be compared to Standard English in the sense of its grammatical aspect:

1. Do not bargain too low

2. Do not buy anything if you do not have money.

\subsubsection{Pidginized English in Interrogative Forms} According to Quirk and Greenbaum (1973:191) there are three types of interrogative form: Yes/No question, Wh- question, and Alternative question.

\section{a. Yes/No Question}

The case is absolutely similar to those found at Seminyak Street pidginized English, but the speakers seem to simplify the question, that is without using auxiliary, to be, as well as modal at the beginning of the sentence. For example:

\section{You alone?}

\section{You from India?}

From the examples above, compared with the Standard English, the forms should be:

1. Do you come here alone?

2. Are you from India?

\section{b. Wh- Questions}

Relating to the language variety at Seminyak Street pidginize English, ether ideas about pidgin variety will be enclosed. In relation to the topic, Todd (1884: 6) again takes part with his ideas that question involving question words like when, where, why, how, etc., are different from statement only in that question forms occur.

Based on the observations that have done at Seminyak Street, there are some data relating to this idea:

- With dollar, how much?

From here, Wh- question is used it is understood that auxiliaries, modals, or to be are often left out by the speakers, to make the language simple but still understandable. If we could standardize them, they should be:

- How much is it in dollar?

\section{c. Alternative Questions}

It is displayed the similar form is also found from the data of Seminyak Street pidginized English:

- You want this big or small?

Comparing with the Standard English, the above data should be:

- Which one do you want to choose? The small or the big one? 
3.2 The Function of Pidginized English that were expressed by Art Shop Attendants in Seminyak Street

After analyzing the forms of pidginized English by art shop attendants in Seminyak Street, the further step is analyzing its functional perspective.

According to Leech (1981) there are four communication function as the function of language, they are: Expressive Function, Signalling Function, Descriptive Function, Argumentative Function. In this discussion, writer found expressive, signalling, and argumentative form at each of the categorized sentences.

\section{IV.CONCLUSION}

Based on foregoing discussion, it can be concluded that the art shop attendants in Seminyak Street have 3 major forms of pidginized English used by them to get interacted by foreigners, namely: 1 . Pidginized English in Positive Forms, 2. Pidginized English in Negative Forms, 3. Pidginized English in Interrogative Forms. In positive forms, pidginized English is used for someone purpose, such as offering their products as well as describing them. In negative forms, it is used for different purpose such as declining the bargaining process. As in interrogative forms, it used for questioning something they want to either know or get clear.

In addition to the forms of structure, pidginized English also has its functions and meanings. Based on the data, it was found that the art shop attendants in Seminyak used 4 kinds of function, namely: Expressive function in order to show their intended message with saying; Signalling Function in order to show their intended messages and feelings without say any word; Descriptive Function in order to describe their merchandises they have; Argumentative Function in order to give an argument and explanation about their merchandise.

\section{REFERENCES}

Adhi, I Ketut. 2012. Pidgin English Used by Peddlers in Sanur Beach Area. Denpasar: Udayana University.

Alobo, Jacob O. (2015). Pidgin English as a Vehicle for the Promotion of Peaceful Co-Existence and National Unity in Nigeria, International Journal of Innovative Research \& Development, Vol 4, pp. $227-211$.

Amakari, Asikiya. (2015). The Effect of Pidgin in the Teaching and Learning of Standard English in Nigeria, International Journal of English and Education, Vol 4, pp. 122-130.

Andika, Agus. 2012. Pidgin English Used by the Art Shop Attendants in Beratan Tourism Object. Denpasar: Udayana University.
Andriyani, Ni Putu Yeni. 2013. An Analysis of Pidgin English Used by Tourism Police at Lake Beratan Tourism Object, Bali, Vol. 1, Singaraja: Ganesha University of Education

Artini. 2008. English Pidgin Used by the Tades in Guwang Art Market. Denpasar: Udayana University.

Dewi, Ni Wayan Sri Puspita. 2010. Pidginized English Used by Art Shop Attendants in Kuta Beach. Denpasar: Udayana University.

Dewi, Puspita. 2010. Pidgnized English Used by Art Shop Attendants in Kuta. Denpasar: Udayana University.

Ekajume-Ilongo, Beatrice. 2016. An Overview of the Pidgin English in Cameroon, International Journal of Humanities Social Sciences and Educations, Vol 3, pp. 154-160.

Hinde, Stephen and Belrose, Guillaume. (2001). Computer Pidgin Language: A new language to talk to your computer? United Kingdom: HP Laboratories. (cited 2001 July. 9. Available from: URL: http://hpl.hp.com/techreports/2001.HPL2001-182.pdf

Holmes, Janet. 1992. An Introduction of Sociolinguistics. USA: Longman.

Hornby, A. S. 2010. Oxford Advance Learner's Dictionary. Oxford: Oxford University Press.

Leeh, Geoffrey. 1983. Principles of Pragmatics. Newyork: Longman

.Mimba, Ni Wayan Septianingsih. 2011. Pidginized English Used by Paradise Massage Club in Sanur. Denpasar: Udayana University.

Ofulue, Christine I. (2012). Nigerian Pidgin and West African Pidgins: A sociolinguistic perspective, Legon Journal of the Humanities, Vol 1.

Pamungkas, Meynar Clavarius Audito. (2014). "Pidginized English Spoken by Handicraft Sellers in Sanur”, Vol 8, Denpasar: Udayana Univesity.

Pratika, Dellis. (2016). The Existence of Indonesian Language: Pidgin or Creole, Journal on English as a Foreign Language, Vol 6.

Primaryantini, Ni Luh Putu Eka. 2006. Pidginized English Spoken by the Vendors at Legian Beach. Denpasar: Udayana University.

Quirk, Randolph and Greenbaum, Sidney. 1973. A Comprehensive Grammar of the English Language. Hongkong: Longman.

Splosky, Bernard. 1998. Sociolinguistics. Oxford: Oxford University Press.

Swari, Made Yuni. 2016. Pidginized English Formulation by Traders at Kerthagosa Museum, Vol 16, pp. 181-188. Denpasar: Udayana University.

Todd, Loreto. 1984. Modern English: Pidgin and Creoles. England: Basil Blackwell. 
Unagolok, Vergilius Bage Ola. 2014. Language Contact between Tourist and Traders in Kuta Beach, Vol 8. Denpasar: Udayana Universty

Wardaugh, Ronald. 1986. An Introduction of Sociolinguistics. Great Britain: Page Bros.

Windu, Adi Jaya. 2015. Language Variants Used by Gamers in Ragnarok Online II: Legend of The Second South East Asia, Vol 11, no. 3, Denpasar: Udayana University.

Winford, Donald. (2010). Journal of Pidgin and Creole Languages. Vol 21, pp. 194-197.

Yakop, I Nyoman. 2008. The Analysis of Pidgin Language Used by Art Shop Attenadants in Ubud. Denpasar: Udayana University. 